\title{
А.В.Ямборко ${ }^{1}$ Ю.В.Еремеева ${ }^{2}$ \\ ДЕТЕКЦИЯ ANAPLASMA PHAGOCYTOPHILUM В КЛЕЩАХ IXODES ANGUSTUS ИЗ МАГАДАНСКОЙ ОБЛАСТИ
}

\author{
${ }^{I}$ ФББУН «Институт биологических проблем Севера» ДВО РАН, Магадан, Российская Федераиия; \\ ${ }^{2}$ ФБУЗ «Центр гигиены и эпидемиологии в Магаданской области», Магадан, Российская Федерация
}

Сообщается о выявлении Anaplasma phagocytophilum в клещах Ixodes angustus генодиагностическим методом. ДНК анаплазм была обнаружена в одном из девяти образцов имаго иксодовых клещей, собранных с фоновых видов грызунов в пригороде города Магадана. Полученные данные могут указывать на существование природного очага гранулоцитарного анаплазмоза на юге Магаданской области, где возбудитель поддерживается в энзоотическом цикле: мелкие млекопитающие - Ixodes angustus.

Ключевые слова: Anaplasma phagocytophilum, анаплазмоз, Ixodes angustus, Магадан.

\section{A.V.Yamborko ${ }^{1}$, Yu.V.Eremeeva ${ }^{2}$}

\section{Detection of Anaplasma phagocytophilum in Ixodes angustus Ticks Found in the Magadan Region}

${ }^{1}$ Institute of Biological Problems of the North, Magadan, Russian Federation; ${ }^{2}$ Center of Hygiene and Epidemiology in the Magadan Region, Magadan, Russian Federation

Reported is the event of detection of Anaplasma phagocytophilum in Ixodes angustus ticks using gene-diagnostic technique. Anaplasma DNA is identified in one of the nine samples of ixodic tick imago collected from common species of rodents in the suburbs of Magadan. The data obtained may be indicative of the existence of natural granulocytic anaplasmosis focus in the south of the Magadan Region where the agent persists in enzootic cycle: small mammals - Ixodes angustus.

Key words: Anaplasma phagocytophilum, anaplasmosis, Ixodes angustus, Magadan.

Гранулоцитарный анаплазмоз - трансмиссивный природно-очаговый зооноз, вызываемый облигатными внутриклеточными паразитами - риккетсиями Anaplasma phagocytophilum. Анаплазмы локализуются в цитоплазматических вакуолях белых кровяных клеток хозяина, главным образом, гранулоцитов [11]. Известно, что A. phagocytophilum вызывает заболевание человека и домашних животных (собак, кошек, лошадей и жвачных) [8]. Природным резервуаром инфекции служат млекопитающие, преимущественно микромаммалии. Векторами гранулоцитарного анаплазмоза в пределах всего нозоареала возбудителя являются иксодовые клещи. В связи с этим, вид A.phagocytophilum практически повсеместно распространен в пределах ареалов его основных переносчиков [2]. Для иксодовых клещей известна трансфазовая передача анаплазм, трансовариальная передача отсутствует $[4,6]$. Поэтому ведущую роль в заражении клещей играет горизонтальный перенос возбудителя при питании на инфицированном хозяине.

Ixodes angustus многочисленный, но в тоже время слабо изученный вид иксодовых клещей. Ареал этого голарктического вида трансконтинентален. В Палеарктике встречается преимущественно на Тихоокеанском побережье (прибрежные районы Магаданской области, юг Камчатки) и прилегающих островах (Сахалин, Хоккайдо, Курильские о-ва), также проникая и в континентальные районы Приморья и среднее Приамурье [5]. Неарктическая часть ареала более обширна. В Северной Америке распростра- нен на западном побережье от Аляски на севере, до Мексики на юге. Далее на восток, ареал сужается в широтном направлении и достигает Атлантического побережья выше 40-й параллели [3]. В Магаданской области I. angustus обнаружен полвека назад В.Г.Беляевым [1] при обследовании Магадана и его окрестностей. Обычен на побережье Тауйской губы Охотского моря (юг Магаданской области), однако севернее $60^{\circ}$ с.ш. иксодовые клещи не встречаются. Основными прокормителями всех жизненных стадий I. angustus являются мелкие грызуны и насекомоядные [5].

В Северной Америке I. angustus служит переносчиком ряда патогенов, таких как Borrelia burgdorferi [9], Babesia microti [7] и A. phagocytophilum [10]. В палеарктической части ареала участие этого вида иксодид в поддержании природных очагов клещевых инфекций не изучено.

Материалом для работы послужили иксодовые клещи, собранные с грызунов в июне-июле 2013 г. в пригороде Магадана (59॰30' с.ш., $150^{\circ} 54^{\prime}$ в.д.). Всего проанализировано девять образцов имаго I. angustus, находившихся на разных стадиях насыщения. Семь экземпляров клещей были сняты с красных полевок (Myodes rutilus), два - с красно-серой полевки (M. rufocanus). Молекулярно-генетические исследования выполнены в ФКУЗ «Хабаровская противочумная станция» Роспотребнадзора. Образцы клещей анализировались индивидуально. Экстракция нуклеиновых кислот из образцов проводилась с использованием наборов реагентов «РИБО-преп» («АмплиСенс», ФБУН 
ЦНИИЭ, Россия). Выявление РНК/ДНК возбудителей клещевых инфекций осуществляли с применением набора реагентов методом ПЦР с гибридизационнофлуоресцентной детекцией «АмплиСенс $T B E V$, B. burgdorferi sl, A. phagocytophilum, E. chaffeensis / E. muris-FL» («АмплиСенс», ФБУН ЦНИИЭ, Россия) в соответствии с инструкцией и методическими рекомендациями производителя.

В одном из девяти образцов обнаружена ДНК A. phagocytophilum (11,1%). Данный экземпляр клеща был снят с красной полевки. РНК/ДНК других возбудителей не выявлена. Таким образом, результаты исследования указывают на возможность существования на юге Магаданской области природного очага гранулоцитарного анаплазмоза, в поддержании которого участвуют клещи I. angustus и их хозяева мелкие млекопитающие. Известно, что имаго этого вида клещей могут присасываться к собакам, кошкам и человеку [12]. Учитывая широкую распространенность и многочисленность клещей I. angustus в окрестностях Магадана, можно предположить, что этот вид иксодид должен иметь некоторое ветеринарное и медицинское значение.

\section{СПИСОК ЛИТЕРАТУРЫ}

1. Беляев В.Г. К фауне эктопаразитов Магаданской области. Докл. Иркутск. противочумного ин-та. 1963; 5:180-5.

2. Васильева И.С. Новые болезни, передаваемые иксодовыми клещами (Ixodidae). Эрлихиозы и анаплазмозы человека. РЭТ-инфо. 2006; 4:1-6.

3. Колонин Г.В. Мировое распространение иксодовых клещей. Род Ixodes. М.: Наука; 1981. 116 с.

4. Рар В.А., Ливанова Н.Н., Панов В.В., Астанин В.Б., Ливанов С.Г., Морозова О.В. Изучение генетического разнообразия анаплазм и эрлихий в паразитарных системах юга Западной Сибири и Урала. Бюлл. сибирской медищины. 2006; 5 (Приложение 1):116-21.

5. Филиппова Н.А. Иксодовые клещи подсемейства Ixodinae. В кн.: Фауна СССР. Паукообразные. Л.: Наука; 1977. T. IV(4). $396 \mathrm{c}$

6. Foley J., Nieto N.C., Adjemian J., Dabritz H., Brown R.N Anaplasma phagocytophilum infection in small mammal hosts of Ixodes ticks, western United States. Emerg. Infect. Dis. 2008; 14(7):1147-50.

7. Goethert H.K., Lubelcyzk C., LaCombe E., Holman M., Rand P., Smith R.P. Jr, Telford S.R. 3rd. Enzootic Babesia microti in Maine. J. Parasitol. 2003; 89(5):1069-71.

8. McQuiston J.H., McCall C.L., Nicholson W.L. Ehrlichiosis and related infections. J. Am. Vet. Med. Assoc. 2003; 223(12): 1750-6.

9. Peavey C.A., Lane R.S., Damrow T. Vector competence of
Ixodes angustus (Acari: Ixodidae) for Borrelia burgdorferi sensu stricto. Exp. Appl. Acarol. 2000; 24(1):77-84.

10. Rejmanek D., Freycon P., Bradburd G., Dinstell J., Foley J. Unique strains of Anaplasma phagocytophilum segregate among diverse questing and non-questing Ixodes tick species in the western United States. Ticks Tick Borne Dis. 2013; 4(6):482-7.

11. Rikihisa Ya. Mechanisms of obligatory intracellular infection with Anaplasma phagocytophilum. Clin. Microbiol. Rev. 2011; 24(3):469-89.

12. Samuel W.M., Pybus M.J., Kocan A.A. Parasitic diseases of wild mammals. 2nd ed. Iowa: Iowa State University Press. Ames; $2001.563 \mathrm{p}$

\section{References}

1. Belyaev V.G. [Concerning the fauna of ectoparasites in the Magadan Region]. Dokl. Irkutsk. Protivochumn. Instituta. 1963; 5:180-5.

2. Vasil'eva I.S. [Emerging tick-borne (Ixodedae) diseases. Human ehrlichioses and anaplasmoses]. RET-info. 2006; 4:1-6.

3. Kolonin G.V. [Dissemination and Distribution of Ixodic Ticks in the World. Ixodes Genus]. M.: Nauka; 1981. 116 p.

4. Rar V.A., Livanova N.N., Panov V.V., Astanin V.B., Livanov S.G., Morozova O.V. [Studies of the genetic diversity of Anaplasma and ehrlichiosis agent in parasitical coenoses in the South of West Siberia and Ural]. Byull. Sibir. Meditsiny. 2006; 5(Appendix 1): 116-21.

5. Filippova N.A. [Ixodidae ticks of Ixodinae subfamily]. In: [USSR

Fauna. Arachnids]. L.: Nauka; 1977. Vol. IV(4). 396 p.

6. Foley J., Nieto N.C., Adjemian J., Dabritz H., Brown R.N. Anaplasma phagocytophilum infection in small mammal hosts of Ixodes ticks, western United States. Emerg. Infect. Dis. 2008; 14(7):1147-50.

7. Goethert H.K., Lubelcyzk C., LaCombe E., Holman M., Rand P., Smith R.P. Jr, Telford S.R. 3rd. Enzootic Babesia microti in Maine. J. Parasitol. 2003; 89(5):1069-71.

8. McQuiston J.H., McCall C.L., Nicholson W.L. Ehrlichiosis and related infections. J. Am. Vet. Med. Assoc. 2003; 223(12):1750-6.

9. Peavey C.A., Lane R.S., Damrow T. Vector competence of Ixodes angustus (Acari: Ixodidae) for Borrelia burgdorferi sensu stricto. Exp. Appl. Acarol. 2000; 24(1):77-84.

10. Rejmanek D., Freycon P., Bradburd G., Dinstell J., Foley J. Unique strains of Anaplasma phagocytophilum segregate among diverse questing and non-questing Ixodes tick species in the western United States. Ticks Tick Borne Dis. 2013; 4(6):482-7.

11. Rikihisa Ya. Mechanisms of obligatory intracellular infection with Anaplasma phagocytophilum. Clin. Microbiol. Rev. 2011; 24(3):469-89.

12. Samuel W.M. Pybus M.J. Kocan A.A. Parasitic diseases of wild mammals. 2nd ed. Iowa: Iowa State University Press. Ames; 2001. 563 p.

Authors:

Yamborko A.V. Institute of Biological Problems of the North. 18, Portovaya St., 685000, Magadan, Russian Federation. E-mail: yambor84@ inbox.ru.

Eremeeva Yu.V. Center of Hygiene and Epidemiology in the Magadan Region. 53, Yakutskaya St., 685000, Magadan, Russian Federation. E-mail: virus@magadancgsen.ru.

Об авторах:

Ямборко А.В. Институт биологических проблем Севера ДВО РАН. Российская Федерация, 685000, Магадан, ул. Портовая, д. 18. Е-mail: yambor84@inbox.ru.

Еремеева Ю.В. Центр гигиены и эпидемиологии в Магаданской области. Российская Федерация, 685000, Магадан, ул. Якутская, д. 53. E-mail: virus@magadancgsen.ru 